\title{
FAKTOR YANG MEMPENGARUHI FINANCIAL MANAGEMENT BEHAVIOR PADA MAHASISWA FOKUS KEILMUAN EKONOMI DAN BISNIS KABUPATEN GRESIK
}

\author{
Yanuar Trisnowati \\ Departemen Manajemen, Universitas Internasional Semen Indonesia \\ Gresik, Indonesia, yanuartrisnowati@gmail.com \\ Marisya Mahdia Khoirina \\ Departemen Manajemen, Universitas Internasional Semen Indonesia \\ Gresik, Indonesia, Marisya.khoirina@uisi.ac.id \\ Firda Alvina Putri \\ Departemen Manajemen, Universitas Internasional Semen Indonesia \\ Gresik, Indonesia, firdaalvina21@gmail.com
}

\begin{abstract}
Background - College students are one component of society that plays an important role for the change of the nation (agent of change). At this moment they are in a situation where they face financial independence and start making responsible decisions. Financial education can be done by providing understanding to the public, especially the younger generation about finances and their management that is good and wise,

Diterima : 10 Desember 2019 Direview : 11 Desember 2019

Direvisi : 16 Juni 2020

Disetujui : 30 Juni 2020 that is why, financial knowledge is needed. Today's society tends to buy things as they wish, so, financial knowledge requires skills and tools for individuals to be able to provide financial decisions and with confidence can manage individual welfare efficiently. Good personal financial management must have at least knowledge so that individuals can apply their knowledge based on their financial attitudes.

Purpose - Determine and analyze the factors that influence the behavior of financial management of college students, focusing on Economics and Business, in Gresik Regency.

Design / methodology / approach - This research methodology uses a descriptive quantitative approach. Chosen population was 2,636 college students and the sample used was 347 students. Data collection taken by questionnaires and analysis was using multiple linear regression.

Finding - Three research variables (1) Financial Attitude, (2) Financial Knowledge, and (3) Locus of Control have an influence on the Financial Management Behavior. College students who tend to have a good financial attitude then they have good financial behavior in managing personal finances. College students with financial knowledge will better understand financial problems and be better in terms of financial behavior. College students who have a good locus of control will be able to measure the risks that occur so that they can easily make a decision and their finances tend to have a level of trust, confidence and good control over their financial management.
\end{abstract}

Research Implication - This research has implications for assessing student behavior in managing personal finances in an effort to meet the needs of education and daily life.

Limitation - In assessing financial management behavior (Financial Management Behavior), this research student only uses 3 variables, namely Financial Attitude, Financial Knowledge, and Locus of Control.

Keywords : Financial, Attitude, Knowledge, Locus of Control, Behavior 


\begin{abstract}
ABSTRAK
Latar belakang - Mahasiswa merupakan salah satu komponen masyarakat yang berperan penting bagi perubahan bangsa (agent of change). Pada saat ini mahasiswa berada pada keadaan dimana mereka menghadapi kemandirian finansial dan mulai melakukan pengambilan keputusan yang bertanggung jawab. Edukasi keuangan dapat dilakukan dengan cara memberikan pemahaman kepada masyarakat terutama generasi muda mengenai keuangan dan pengelolaannya yang secara baik dan bijak sehingga financial knowledge pada saat ini sangat dibutuhkan. Masyarakat pada saat ini cenderung membeli sesuatu sesuai dengan keinginan sehingga financial knowledge memerlukan skill dan alat bagi individu untuk dapat memberikan keputusan keuangan dan dengan rasa percaya diri dapat mengelola kesejahteraan individu secara efisien. Pengelolaan keuangan pribadi yang baik harus memiliki sedikitnya pengetahuan sehingga individu dapat mengaplikasikan pengetahuannya tersebut berdasarkan attitude keuangan yang dimilikinya.
\end{abstract}

Tujuan - Penelitian ini bertujuan untuk mengetahui dan menganalisis faktor-faktor yang mempengaruhi perilaku manajemen keuangan mahasiswa fokus keilmuan Ekonomi dan Bisnis di Kabupaten Gresik.

Desain / metodologi/ pendekatan - Metodologi penelitian ini menggunakan pendekatan kuantitatif deskriptif. Jumlah populasi 2.636 mahasiswa dan sampel yang digunakan sebanyak 347 mahasiswa. Metode pengambilan data dengan kuesioner dan metode analisis data dengan menggunakan regresi linear berganda.

Temuan - Ketiga variabel penelitian yaitu Financial Attitude, Financial Knowledge, dan Locus of Control memiliki pengaruh terhadap Financial Management Behavior. Mahasiswa yang cenderung memiliki financial attitude yang baik maka mereka memiliki perilaku keuangan yang baik pula dalam mengatur keuangan pribadi. Mahasiswa dengan financial knowledge akan lebih memahami masalah keuangan serta lebih baik dalam hal perilaku keuangannya. Mahasiswa yang memiliki locus of control yang baik akan mampu mengukur resiko yang terjadi sehingga mereka dengan mudah untuk dapat mengambil sebuah keputusan dan keuangannya cenderung memiliki tingkat kepercayaan, keyakinan dan pengendalian yang baik terhadap pengelolaan keuangan mereka.

Implikasi penelitian - Penelitian ini dapat berimplikasi pada menilai perilaku mahasiswa dalam mengelola keuangan pribadinya untuk upaya memenuhi kebutuhan pendididikan dan kehidupan sehariharinya.

Batasan penelitian - Dalam menilai perilaku manajemen keuangan (Financial Management Behavior) mahasiswa penelitian ini hanya menggunakan 3 variabel yaitu Financial Attitude, Financial Knowledge, dan Locus of Control.

Kata Kunci : Financial, Attitude, Knowledge, Locus of Control, Behavior

\section{PENDAHULUAN}

Perilaku keuangan masyarakat Indonesia yang cenderung konsumtif kemudian menimbulkan berbagai perilaku keuangan yang tidak bertanggungjawab lainnya seperti kurangnya kegiatan menabung, investasi, perencanaan dana darurat dan penganggaran dana untuk masa depan. Masyarakat Indonesia belum menabung secara maksimal. Dijajaran negara-negara
Asia Tenggara pun, Indonesia menempati urutan terbawah dalam hal total nominal tabungan dan kebiasaan menabung. Tingkat pemahaman finansial Indonesia masih tergolong rendah dengan hanya 1 dari 3 orang saja yang paham finansial namun peringkat literasi Indonesia termasuk cukup tinggi dibandingkan dengan negara lain di ASEAN. Berdasarkan data dari Worldbank yang diperoleh dari riset terhadap 150 ribu 
orang yang tersebar di 140 negara, Indonesia memperoleh score sebesar 32\% untuk tingkat pemahaman finansial. Nilai ini lebih kecil sedikit dari score rata-rata seluruh negara, yaitu 33\%. Secara keseluruhan, Indonesia memang cukup unggul di antara kebanyakan negara ASEAN, namun kalah jauh dari negara tetangga, yaitu Singapura (59\%) dan Malaysia (36\%). Rendahnya literasi keuangan masyarakat Indonesia akan berdampak pada keputusan keuangan yang akan diambil, misalnya kerugian keuangan, masalah pengeluaran dan konsumsi cenderung boros, penggunaan kartu kredit yang tidak bijaksana, serta investasi yang tidak tepat. Akibatnya, secara agregat akan berpengaruh terhadap perekonomian Indonesia. Karena, dasarnya perekonomian suatu negara akan kuat apabila ditunjang dengan pengetahuan masyarakat terhadap keuangan yang cukup tinggi.

Pada saat ini praktik manajemen keuangan pada remaja mendapatkan perhatian serius dari berbagai organisasi, seperti pemerintah, lembaga keuangan, universitas dan lain sebagainya. Pengelolaan terhadap sumber keuangan yang efektif sangat diperlukan remaja demi kesejahteraan kehidupannya untuk dapat mengambil keputusan keuangan yang tepat dan bijak. Hal ini mengakibatkan remaja harus memiliki pengetahuan dasar tentang keuangan dan bagaimana cara untuk dapat mengaplikasikan pengetahuan tersebut dengan sikap yang dimiliki individu sesuai dengan perilaku individu yang bersangkutan. Memiliki penguasaan ilmu serta skill di bidang keuangan mendorong individu untuk memahami dan ikut terlibat pada isu-isu nasional di bidang keuangan seperti biaya perawatan kesehatan, pajak, investasi serta dapat memiliki akses ke dalam sistem keuangan tersebut (Nababan dan Sadalia, 2013). Sehingga dalam melakukan pengelolaan terhadap keuangan, individu memiliki pengalaman yang berbeda-beda tergantung dari bagaimana individu memperoleh pengetahuan tentang pengelolaan keuangan tersebut. Diketahui juga bahwa generasi muda jarang memperaktikkan kemampuan keuangan dasar seperti budgeting, perencanaan tabungan harian atau perencanaan untuk kebutuhan jangka panjang dan lain sebagainya (Mien, 2015).

Financial Knowledge pada saat ini sangat dibutuhkan, karena masyarakat pada saat ini cenderung membeli sesuatu sesuai dengan keinginan mereka. Financial knowledge memerlukan skill dan alat bagi individu untuk dapat memberikan keputusan keuangan dan dengan rasa percaya diri dapat mengelola kesejahteraan individu secara efisien dan meningkatkan permintaan kompetensi keuangan untuk pelayanan keuangan yang lebih baik (Ahsan, 2013). Meningkatkan financial knowledge serta membuat keputusan keuangan menjadi yang lebih baik 
memungkinkan perencanaan yang lebih matang dan mampu memanajemen setiap tahap kehidupan seperti pembelajaran, pembelian rumah dan masa pensiun (Mahdzan \& Tabiani, 2013). Dengan adanya pembelajaran mengenai masalah keuangan diharapkan individu dapat meningkatkan financial knowledge sehingga individu mampu untuk mengelola keuangan maupun mengambil tindakan keputusan keuangan dengan baik. Pengelolaan keuangan pribadi yang baik harus memiliki sedikitnya pengetahuan sehingga individu dapat mengaplikasikan pengetahuannya tersebut berdasarkan attitude keuangan yang dimilikinya.

Attitude merupakan penggambaran yang dapat diketahui melalui kepribadian seseorang berupa gerakan fisik atau nonfisik maupun pemikiran seseorang terhadap sesuatu objek ataupun keadaan (Yulianti dan Silvy, 2013). Sedangkan financial attitude adalah sikap yang ditunjukkan oleh individu untuk dapat mengelola keuangan dengan baik.

Financial management behavior adalah kemampuan seseorang dalam mengatur yaitu perencanaan, penganggaran, pemeriksaan, pengelolaan, pengendalian, pencarian dan penyimpanan dana keuangan sehari-hari. Munculnya financial management behavior, merupakan dampak dari besarnya hasrat seseorang untuk memenuhi kebutuhan hidupnya sesuai dengan tingkat pendapatan yang diperoleh
(Kholilah et., al 2013). Financial management behavior berhubungan dengan tanggung jawab keuangan seseorang mengenai cara pengelolaan keuangan mereka. Tanggung jawab keuangan adalah proses pengelolaan uang dan aset lainnya dengan cara yang dianggap produktif. Tugas utama pengelolaan uang adalah proses penganggaran. Financial management behavior yang sehat ditunjukkan oleh aktifitas perencanaan, pengelolaan serta pengendalian keuangan yang baik.

Mahasiswa merupakan salah satu komponen masyarakat yang berperan penting bagi perubahan bangsa lagent of change). Kehidupan yang serba mahal saat ini membuat mahasiswa harus bisa menyiapkan dan merencanakan keuangan dengan baik. Membuat rencana keuangan atau mengelola keuangan seseorang harus memiliki pengetahuan keuangan supaya seseorang memiliki prilaku yang lebih bertanggung jawab secara keuangannya (Hilgert et.al, 2003). Upaya dalam meningkatkan pengetahuan masyarakat mengenai keuangan dapat dilakukan dengan cara melakukan edukasi keuangan.

\section{TINJAUAN PUSTAKA}

\section{Financial Management Behavior}

Financial management behavior menjadi gambaran cara individu berperilaku ketika dihadapkan dengan keputusan keuangan yang harus dibuat. Perilaku keuangan juga dapat diartikan sebagai suatu teori yang 
didasarkan atas ilmu psikologi yang berusaha memahami bagaimana emosi dan penyimpanan kognitif mempengaruhi perilaku investor. Di tengah perkembangan ekonomi global saat ini, setiap individu harus dapat menjadi konsumen yang cerdas untuk dapat mengelola keuangan pribadi dengan cara membangun melek finansial yang mengarah pada perilaku keuangan yang sehat. Kendali diri merupakan perilaku keuangan yang sangat bermanfaat bila dipahami dan dapat diterapkan di kehidupan seharihari (Lubis, et al., 2013).

\section{Financial Attitude}

Financial Attitude yaitu memandang uang sebagai power/freedom, reward for efforts, atau evil. Dengan kata lain sikap terhadap uang seseorang adalah bagaimana seseorang memiliki pandangan mengenai uang yakni uang sebagai sumber kekuatan dan kebebasan, prestasi, ataupun sumber kejahatan. Oleh sebab itu Financial Attitude sangat berperan penting dalam menentukan Financial Management Behavior seseorang. Financial Attitude dapat membentuk cara orang untuk menghabiskan, menyimpan, menimbun, dan membuang uang.

\section{Financial Knowledge}

Financial Knowledge merupakan kemampuan untuk memahami, menganalisis dan mengelola keuangan untuk membuat suatu keputusan keuangan yang tepat agar terhindar dari masalah keuangan. Kehidupan yang berkualitas dan terhindar dari masalah keuangan pasti di inginkan oleh setiap individu. Dalam mencapai kehidupan yang berkualitas dan terhindar dari masalah keuangan tentunya harus di dasarkan pada pengetahuan keuangan yang baik dalam setiap pengambilan keputusan. Kurangnya literasi keuangan menyebabkan individu lebih cenderung memiliki masalah hutang, lebih terlibat dengan biaya kredit yang lebih tinggi dan kecil kemungkinannya untuk merencanakan masa depan (Lusardi, 2008).

\section{Locus of Control}

Locus of Control mengacu pada sejauh mana individu percaya bahwa mereka dapat mengontrol peristiwa yang mempengaruhi dan merupakan salah satu variabel yang mempengaruhi perilaku keuangan. Locus of Control memiliki dua dimensi: Locus of Control internal dan Locus of Control eksternal. Mereka dengan Locus of Control internal lebih cenderung meyakini bahwa nasib atau kejadian dalam hidupnya berada di bawah kontrol dirinya, sedangkan mereka dengan Locus of Control eksternal cenderung meyakini bahwa lingkungan memiliki kontrol terhadap nasib (Kholilah, 2013).

\section{Hipotesis}

Menurut Amminatuzzahra

menunjukkan bahwa semakin baik sikap atau mental keuangan seseorang maka perilaku keuangan seseorang tersebut semakin baik. Semakin baik sikap individu terhadap keuangan pribadinya maka 
individu tersebut semakin baik dalam melakukan manajemen keuangan. Sikap keuangan yang baik ternyata tidak diimbangi dengan perilaku keuangan yang baik. Sehingga dirumuskan hipotesis sebagai berikut :

\section{H1: Financial Attitude berpengaruh} terhadap Financial Management

\section{Behavior.}

Financial knowledge tidak hanya mampu membuat seseorang menggunakan uang dengan bijak, namun juga dapat memberi manfaat pada ekonomi. Seseorang dengan pengetahuan finansial lebih tinggi mampu membuat keputusan yang baik bagi keluarga mereka dan dengan demikian berada dalam posisi untuk meningkatkan keamanan ekonomi dan kesejahteraan mereka, selain itu seseorang yang berpengetahuan keuangan yang membuat pilihan informasi sangat penting untuk sebuah pasar yang efektif dan efisien (Hilgert dan Hogarth, 2003). Sehingga dirumuskan hipotesis sebagai berikut :

H2: Financial Knowledge berpengaruh terhadap Financial Management Behavior.

Amanah et al. (2016), mengatakan bahwa ketika external locus of control seseorang semakin tinggi maka perilaku pengelolaan keuangannya juga akan semakin buruk yang menyatakan bahwa locus of control berpengaruh terhadap financial management behavior. Sehingga dirumuskan hipotesis sebagai berikut :

\section{H3: Locus of Control berpengaruh terhadap Financial Management \\ Behavior.}

\section{KERANGKA KONSEPTUAL PENELITIAN}

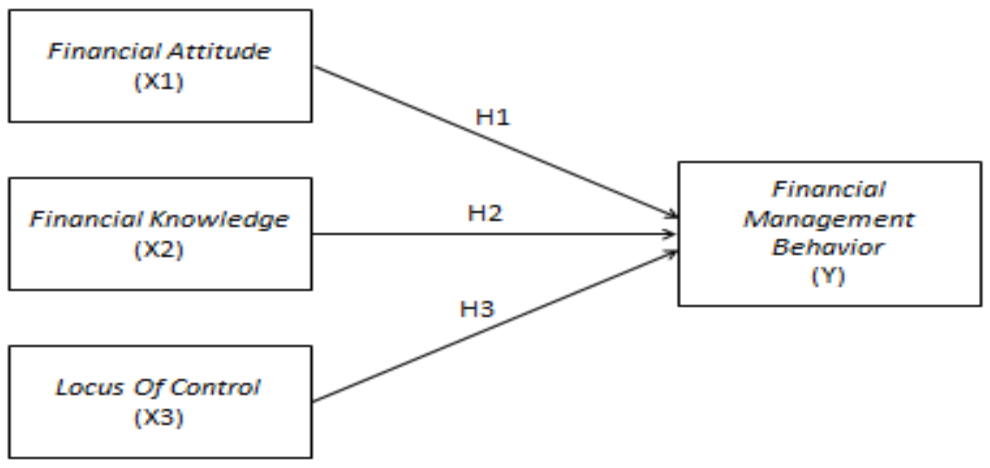

Gambar 1. Kerangka Konseptual

\section{METODOLOGI PENELITIAN}

Metode penelitian yang digunakan dalam penelitian ini adalah metode penelitian kuantitatif dengan pendekatan deskriptif. Pendekatan deskriptif menurut Sugiyono
(2015) adalah metode penelitian deskriptif ini dilakukan untuk mengetahui keberadaan variabel mandiri, baik hanya pada satu variabel atau lebih (variabel yang berdiri sendiri atau variabel bebas) tanpa 
membuat perbandingan variabel itu sendiri dan mencari hubungan dengan variabel lain. Metode deskriptif ini merupakan metode yang bertujuan untuk mengetahui sifat serta hubungan yang lebih mendalam antara dua variabel dengan cara mengamati aspek-aspek tertentu secara lebih spesifik untuk memperoleh data yang sesuai dengan masalah yang ada dengan tujuan penelitian, dimana data tersebut diolah, dianalisis, dan diproses lebih lanjut dengan dasar teoriteori yang telah di pelajari sehingga data tersebut dapat ditarik sebuah kesimpulan.

\section{Populasi dan Sampel}

Populasi dalam penelitian ini adalah mahasiswa aktif Kabupaten Gresik Fokus Keilmuan Ekonomi dan Bisnis. Terdiri dari tiga Universitas, yaitu Universitas Internasional Semen Indonesia, Universitas Muhammadiyah Gresik, dan Universitas Gresik. Populasi sejumlah 2636 orang. Dengan menggunakan metode Proportional Randem Sampling yang dihitung dari jumlah populasi di ketiga Universitas, maka diperoleh jumlah sampel sebanyak 347 mahasiswa dengan proporsi 112 dari Universitas Internasional Semen Indonesia, 184 dari Universitas Muhammadiyah Gresik, dan 51 dari Universitas Gresik.

\section{Variabel Penelitian}

Variabel Independen penelitian ini adalah Sikap Keuangan (Financial Attitude) (X1), Pengetahuan Keuangan (Financial
Knowledge) (X2), dan Kepribadian (Locus Of Control) (X3). Sedangkan variabel Dependen adalah Financial Management Bahavior (Y).

\section{Sumber Data}

Data dalam penelitian merupakan data primer yang diperoleh dengan menyebarkan kuesioner sebanyak 347 kepada mahasiswa di Kabupaten Gresik

\section{Metode Analisis Data}

\section{Regresi Linear Berganda}

Regresi linier berganda ditujukan untuk menentukan hubnngan linier antara beberapa variabel bebas dengan variabel terikat. Analisis ini digunakan untuk mengetahui arah hubungan antara variabel independen dengan variabel dependen apakah setiap variabel independen berhubungan positif atau negative dan untuk memprediksi nilai dari variabel dependen apabila nilai variabel independen mengalami kenaikan atau penurunan. Adapun persamaan regresi berganda yang digunakan dalam penelitian ini adalah:

$$
Y=a+\beta_{1} X_{1}+\beta_{2} X_{2}+\beta_{3} X_{3}+\varepsilon
$$

Keterangan:

Y nilai variabel Financial Management

Behavior)

a konstanta nilai $\mathrm{Y}$ apabila $\mathrm{X}=0$ )

$X_{1}$ nilai variabel Financial Attitude $\left(X_{1}\right)$

$X_{2}$ nilai variabel Financial Knowledge $\left(X_{2}\right)$

$X_{3}$ nilai variabel Locus Of Control $\left(X_{3}\right)$

$\beta_{1}$ koefisien regresi variabel $X_{1}$

$\beta_{2}$ koefisien regresi variabel $X_{2}$

$\beta_{3}$ koefisien regresi variabel $X_{3}$

$\varepsilon$ Error Term 


\section{Uji t (Parsial)}

Uji t pada dasarnya menunjukan sebarapa jauh pengaruh satu variabel independen secara individual dalam menerangkan variasi-variabel dependen (Ghozali, 2016). Uji ini dilakukan untuk menentukan signifikan atau tidaknya masing-masing nilai koefisien secara sendiri-sendiri terhadap variabel terikat. Uji $\mathrm{t}$ dilakukan dengan membandingkan antara $\mathrm{t}$ hitung tabel. Tingkat signifikan yang digunakan pada $\mathrm{a}=0,05(5 \%)$ atau tingkat keyakinan sebesar 0,95 (95\%).

\section{Uji Koefisien Determinasi}

Menurut Santoso dalam Priyatno (2008), Adjusted $\mathrm{R}$ square adalah $\mathrm{R}$ square yang telah disesuaikan nilai ini selalu lebih kecil dari $\mathrm{R}$ square dari angka ini bisa memiliki harga negatif, bahwa untuk regresi dengan lebih dari dua variabel bebas digunakan Adjusted $\mathrm{R}^{2}$ sebagai koefisie detrminasi.

Koefisien determinasi Adjusted $R^{2}$ ) digunakan untuk mengetahui tingkat ketepatan paling baik dalam analisa regresi dimana hal yang ditunjukan oleh besarnya koefisien determinasi $\left(\mathrm{R}^{2}\right)$ antara 0 (nol) dan 1 (satu). Koefisien determinan berkisar antara nol sampai dengan satu $\left(0 \leq \mathrm{R}^{2} \leq 1\right)$. Hal ini berarti bila $R^{2}=0$ menunjukkan tidak adanya pengaruh antara variabel independen terhadap variabel dependen, bila Adjusted $\mathrm{R}^{2}$ semakin besar mendekati 1 menunjukkan semakin kuatnya pengaruh variabel independen terhadap variabel dependen dan bila Adjusted $\mathrm{R}^{2}$ semakin kecil bahkan mendekati nol, maka dapat dikatakan semakin kecil pula pengaruh variabel independen terhadap variabel dependen.

\section{HASIL DAN PEMBAHASAN}

\section{Hasil Analisis Regresi}

Analisis regresi linier berganda bertujuan untuk mengetahui seberapa besar pengaruh financial attitude, financial knowledge, locus of control tehadap financial management behavior pada mahasiswa Fokus Keilmuan Ekonomi dan Bisnis Kabupaten Gresik. Adapun variabel dependennya yaitu financial management behavior sedangkan independennya yaitu financial attitude, financial knowledge, dan locus of control. Hasil pengolahan data dengan menggunakan program SPSS diperoleh sebagai berikut:

Tabel 1

Hasil Analisis Regresi

\begin{tabular}{cc} 
& B \\
\hline Constant & -5.668 \\
X1 & 1.299 \\
X2 & 0.114 \\
X3 & 0.359 \\
\hline
\end{tabular}

Sumber: data hasil penelitian (diolah) 
Berdasarkan hasil perhitungan, diperoleh bentuk persamaan regresi linier berganda sebagai berikut:

$$
Y=-5,668+1,299 X_{1}+0,114 X_{2}+0,359 X_{3}
$$

$\mathrm{Y}$ adalah financial management behavior, $\mathrm{X}_{1}$ adalah financial attitude, $\mathrm{X}_{2}$ adalah financial knowledge, dan $\mathrm{X}_{3}$ adalah financial management behavior. Berdasarkan persamaan diatas dapat diinterprestasikan:

Nilai konstanta sebesar -5,668 artinya jika variabel terikat financial management behavior $(\mathrm{Y})$ dipengaruhi oleh ketiga variabel bebasnya, X1, X2, X3=0, maka besarnya rata-rata financial management behavior bernilai $-5,668$.

Nilai dari financial attitude adalah 1,299, artinya koefesien regresi untuk variabel financial attitude bernilai positif, menunjukan adanya hubungan yang searah antara financial attitude dan financial management behavior. Koefisien regresi variabel financial attitude adalah sebesar 1,299, ini diartikan bahwa setiap pertambahan financial attitude sebesar satu satuan maka akan menyebabkan meningkatnya financial management behavior sebesar 1,299.

Nilai dari financial knowledge adalah 0,114, artinya koefesien regresi bernilai positif, menunjukan adanya hubungan yang searah financial knowledge dan financial management behavior. Koefisien regresi variabel financial knowledge adalah sebesar 0,114, ini diartikan bahwa setiap pertambahan financial knowledge sebesar satu satuan maka akan menyebabkan meningkatnya financial management behavior sebesar 0,114.

Nilai dari locus of control adalah 0,359, artinya koefesien regresi untuk variabel locus of control bernilai positif, menunjukan adanya hubungan yang searah locus of control dan financial management behavior. Koefisien regresi variabel locus of control adalah sebesar 0,359, ini diartikan bahwa setiap pertambahan locus of control sebesar satu satuan maka akan menyebabkan meningkatnya financial management behavior sebesar 0,359.

Tabel 2 menunjukkan hasil dari uji hipotesis secara parsial (uji t) variabel financial attitude $\left(\mathrm{X}_{1}\right)$ memiliki nilai $t_{\text {hitung }}>$ $t_{\text {tabel }}(41,804>1,967) \quad$ dengan nilai signifikasi < dari nilai signifikasi yang disyaratkan $(0,000<0,05)$ yang artinya bahwa financial attitude memiliki pengaruh signifikan terhadap financial management behavior pada mahasiswa fokus keilmuan ekonomi dan bisnis kabupaten gresik. Dengan demikian hipotesis 1 menyatakan bahwa financial attitude terdapat pengaruh terhadap financial management behavior maka dengan hasil tersebut diterima.

Berdasarkan hasil penelitian yang dilakukan sejalan dengan Madern dan Schors (2012) yang menyatakan bahwa financial attitude memiliki pengaruh terhadap financial management behavior. 
Tabel 2

Hasil Uji Parsial T

\begin{tabular}{cccc} 
Variabel & T & Sig. & Hasil \\
\hline \hline Financial Attitude & 41.804 & 0.000 & Berpengaruh \\
Financial Knowledge & 4.343 & 0.000 & Berpengaruh \\
Locus Of Control & 10.300 & 0.000 & Berpengaruh
\end{tabular}

Sumber: data hasil penelitian (diolah)

Hasil dari uji hipotesis secara parsial (uji t) variabel financial knowledge $\left(\mathrm{X}_{2}\right)$ memiliki nilai $t_{\text {hitung }}>t_{\text {tabel }}(4,343>1,967)$ dengan nilai signifikasi < dari nilai signifikasi yang disyaratkan $(0,000<0,05)$ yang artinya bahwa financial knowledge memiliki pengaruh signifikan terhadap financial management behavior pada mahasiswa fokus keilmuan ekonomi dan bisnis kabupaten gresik. Dengan demikian hipotesis 2 menyatakan bahwa financial knowledge terdapat pengaruh terhadap financial management behavior maka dengan hasil tersebut diterima.

Berdasarkan hasil penelitian sejalan dengan yang dilakukan oleh Hilgert dan Hogarth (2003) yang menyatakan seseorang dengan pengetahuan finansial lebih tinggi mampu membuat keputusan yang baik bagi keluarga mereka dan dengan demikian berada dalam posisi untuk meningkatkan keamanan ekonomi dan kesejahteraan mereka, selain itu seseorang yang berpengetahuan keuangan yang membuat pilihan informasi sangat penting untuk sebuah pasar yang efektif dan efisien. Sehingga menunjukkan bahwa financial knowledge memiliki pengaruh terhadap financial management behavior.
Hasil dari uji hipotesis secara parsial (uji t) variabel locus of control $\left(\mathrm{X}_{3}\right)$ memiliki nilai $t_{\text {hitung }}>t_{\text {tabel }}(10,300>1,967)$ dengan nilai signifikasi < dari nilai signifikasi yang disyaratkan $(0,000<0,05)$ yang artinya bahwa locus of control memiliki pengaruh signifikan terhadap financial management behavior pada mahasiswa fokus keilmuan ekonomi dan bisnis kabupaten gresik. Dengan demikian hipotesis 3 menyatakan bahwa locus of control terdapat pengaruh terhadap financial management behavior maka dengan hasil tersebut diterima.

Berdasarkan hasil penelitian sejalan dengan yang dilakukan oleh Kholilah dan Iramani (2013), seseorang dengan internal locus of control baik, maka perilaku pengelolaan keuangannya akan semakin baik. Sehingga ketika seseorang bisa mengendalikan dirinya dari dalam untuk menggunakan uang seperlunya saja atau menggunakan uangnya sesuai kebutuhan, kemungkinan seseorang tersebut juga akan melakukan perilaku manajemen keuangannya dengan baik.

Aminatuzzahra (2014), mengatakan bahwa ketika external locus of control seseorang semakin tinggi maka perilaku pengelolaan keuangannya juga akan semakin buruk dari pernyataan dari 
keduanya maka locus of control berpengaruh terhadap financial management behavior.

\section{Pembahasan}

Financial attitude yang mempengaruhi financial management behavior menjadikan mahasiswa Fokus Keilmuan Ekonomi dan Bisnis Kabupaten Gresik untuk dapat melakukan pengelolaan keuangan yang lebih baik lagi terhadap keuangan pribadi. Hal ini akan mempengaruhi mahasiswa untuk dapat menentukan tindakan seperti apa yang harus mereka lakukan yang kemudian mereka aplikasikan kedalam sikap. Mahasiswa yang memiliki financial attitude yang baik akan menjadi suatu kebiasaan bagi mahasiswa dan akan menjadi perilaku yang akan sulit untuk diubah. Dengan mahasiswa yang cenderung memiliki financial attitude yang baik maka mereka memiliki perilaku keuangan yang baik pula dalam mengatur keuangan pribadi. Mahasiswa tidak akan mengalami kesulitan terhadap pengelolaan keuangan jika mahasiswa tersebut memiliki sikap dan perilaku bagaimana cara pengelolaan keuangan yang seharusnya mereka terapkan didalam kehidupan mereka, sehingga dengan begitu membuat mereka mudah untuk mengambil sebuah keputusan. Tetapi berbeda dengan mahasiswa yang tidak memiliki financial attitude yang baik ini akan mengalami kesulitan bagi mereka dalam berperilaku terhadap keuangan pribadi. Hal ini terjadi ketika mahasiswa tidak mampu untuk mengambil tindakan apa yang akan mereka lakukan terhadap keputusan keuangan. Akhirnya akan menjadi kebiasaan buruk dan menjadi sulit untuk bersikap terhadap keuangan mereka.

Financial knowledge mempengaruhi financial management behavior menjadikan mahasiswa Fokus Keilmuan Ekonomi dan Bisnis Kabupaten Gresik untuk memahami pengetahuan tentang pengelolaan keuangan. Hal ini akan mempengaruhi mahasiswa untuk dapat menetukan perilaku apa yang harus mereka lakukan untuk mengambil sebuah keputusan. Mahasiswa yang memiliki financial knowledge yang baik akan mampu menggunakan uang dengan bijak serta dapat memberikan manfaat terhadap kehidupan mereka. Mahasiswa dengan financial knowledge akan lebih memahami masalah keuangan serta lebih baik dalam hal perilaku keuangannya. Semakin baik pengetahuan tentang keuangan maka semakin baik pula seseorang dalam mengelola keuangannya. Berbeda dengan mahasiswa yang memiliki pengetahuan keuangan yang rendah cenderung tidak mempunyai perilaku yang baik terhadap pengelolaan keuangan pribadi ataupun dalam pengambilan keputusan. Hal ini terjadi ketika mahasiswa tidak mengetahui dan memahami pentingnya financial knowledge yang sebenarnya. Pengelolaan 
dan pengetahuan keuangan akhirnya akan buruk bagi mahasiswa yang tidak bisa mengelola keuangannya dengan bijak.

Locus of control yang mempengaruhi financial management behavior menjadikan mahasiswa Fokus Keilmuan Ekonomi dan Bisnis Kabupaten Gresik dapat berhati-hati terhadap pengontrolan diri mereka yang dapat mempengaruhi tingkat kepercayaan dan keyakinan dalam mengendalikan suatu peristiwa pada keuangan pribadi. Hal ini akan mempengaruhi mahasiswa untuk dapat menetukan perilaku apa yang harus mereka lakukan untuk mengambil sebuah keputusan. Mahasiswa yang memiliki locus of control yang baik akan mampu mengukur resiko yang terjadi sehingga mereka dengan mudah untuk dapat mengambil sebuah keputusan dan keuangannya cenderung memiliki tingkat kepercayaan, keyakinan dan pengendalian yang baik terhadap pengelolaan keuangan mereka. Mahasiswa akan mengetahui resiko yang mungkin akan terjadi jika mahasiswa mampu membuat perencanaan keuangan yang baik, sehingga mereka mampu menghindari kemungkinan resiko kedepanya dan dapat mengmbil keputusan dengan mudah. Berbeda dengan mahasiswa yang memiliki locus of control yang rendah cenderung tidak mempunyai kontrol yang baik terhadap diri mereka dalam pengelolaan keuangan pribadi. Hal ini terjadi ketika mahasiswa tidak mengetahui dan memahami pentingnya locus of control yang sebenarnya. Akhirnya akan menjadi buruk bagi mahasiswa untuk dapat mengendalikan pengelolaan secara baik dan akan sulit juga bagi mahasiswa dalam mengambil sebuah keputusan.

\section{KESIMPULAN}

Penelitian ini bertujuan untuk melihat pengaruh financial attitude, financial knowledge dan locus of control terhadap financial management behavior mahasiswa Fokus Keilmuan Ekonomi dan Bisnis Kabupaten Gresik. Berdasarkan Analisis data dan pembahasan dari hasil penelitian, maka dapat diambil kesimpulan

1. Berdasarkan uji regresi yang dilakukan pada hipotesis pertama, dapat disimpulkan bahwa financial attitude berpengaruh signifikan terhadap financial management behavior pada mahasiswa.

Berdasarkan hasil hasil analisis yang telah dilakukan dpaat terlihat bahwa nilai signifikansinya lebih kecil dari 0,05. Hal ini menandakan bahwa financial attitude akan mempengaruhi perilaku mahasiwa Fokus Keilmuan Ekonomi dan Bisnis Kabupaten Gresik untuk mengambil keputusan.

2. Variabel financial knowledge berpengaruh signifikan terhadap financial management behavior pada mahasiswa.

Berdasarkan hasil pengolahan diperoleh nilai signifikansinya lebih kecil dari 0,05. Hal ini menunjukan bahwasanya 
mahasiswa Fokus Keilmuan Ekonomi dan Bisnis Kabupaten Gresik memiliki pengetahuan mengenai keuangan maka mereka akan memiliki kemampuan juga untuk dapat merencanakan dan mengelola keuangan personal.

3. Variabel locus of control berpengaruh signifikan terhadap financial management behavior pada mahasiswa. Hasil analisis regresi linear berganda memperlihatkan nilai signifikansi sebesar 0,00 yang artinya lebih kecil dari 0,05. Hal ini menunjukan bahwasanya mahasiswa Fokus Keilmuan Ekonomi dan Bisnis Kabupaten Gresik memiliki kontrol yang baik maka akan mempengaruhi mereka dalam pengambilan keputusan.

\section{IMPLIKASI PENELITIAN}

Penelitian ini diharapkan dapat menambah referensi di bidang Financial Management terutama pada topik Financial Behavior. Perilaku pengelolaan keuangan mahasiswa sangat dipengaruhi oleh ketiga variabel yang digunakan dalam penelitian yaitu Financial Attitude, Financial Knowledge, dan Locus of Control.

\section{ACKNOWLEDGEMENT}

Penulis mengucapkan terima kasih kepada anggota peneliti dan mahasiswa yang telah membantu terselesaikannya penelitian ini. Peneliti juga mengucapkan terimakasih atas kerjasama yang baik dan atas izin survey pengambilan data yang diberikan oleh Universitas Muhammadiyah Gresik dan Universitas Gresik. Penelitian ini mendapatkan hibah riset bersaing oleh Universitas Internasional Semen Indonesia.

\section{DAFTAR PUSTAKA}

Ahsan, M. H. (2013). Financial Literacy Research On Graduate Students In Malaysia: Current Literature And Research Oppoturnities. International Journal of Education and Research.

Amanah, Ersha dkk. 2016. Pengaruh Financial Knowledge, Financial Attitude Dan External Locus Of Control Terhadap Personal Financial Management Behavior Pada Mahasiswa S1 Universitas Telkom. E-Proceeding Of Management: volume 3, No.2 Agustus 2016

Aminatuzzahra. (2014). Persepsi Pengaruh Pengetahuan Keuangan, Sikap Keuangan, Sosial Demografi Terhadap Perilaku Keuangan Dalam Pengambilan Keputusan Investasi Individu. Journal Financial Behaviour.

Dewi Priyatno, 2008, Mandiri Belajar SPSS - Bagi Mahasiswa dan Umum, Yogyakarta: MediaKom

Ghozali, I. (2016). Aplikasi Analisis Multivariate dengan program SPSS. Semarang: UNDIP.

Hilgert, M. A., Hogarth, J. M., \& Beverly, S. G. (2003). Household financial management: The connectionbetween knowledge and behavior. Federal ReserveBulletin, pp. 309-322 
Kholilah, Naila A., Iramani. (2013). Studi Financial Management Behavior Pada Masyarakat Surabaya. Journal of Business and Banking, 3 (1), 69-80.

Lubis, A., Sadalia, I., \& Fachrudin, K. A. (2013). Perilaku Keuangan Investor. Medan: USU Press.

Lusardi, A. (2008). Household Saving Behavior. The Role of Financial Literacy, Information, and Financial Education Programs. NBER Working Paper.

Madern, Tamara, Schors Anna Van Der. 2012.Financial attitudes and skills as early-warning signs of financial problems.Dutch National Institute for Family Finance Information.

Mahdzan, N. S., \& Tabiani, S. (2013). The Impact of Financial Literacy on Individual Saving: an Exploratory Study in Malaysian Context. Transformations in Business \& Economcs , 4155.

Mien., Thao, (2015). "Factors Affecting Personal Financial Management Behavior: Evidence From Vietnam," presented at the Proceedings of The Second Asia Pasific Conference on Global Business, Economics, Finance and Social Sciences (AP 15 Vietnam Conference).

Nababan D dan Sadalia I. (2013). Analisis Personal Financial Literacy dan Financial Behavior Mahasiswa Strata I Fakultas Ekonomi Universitas Sumatera Utara. Repository jurnal Universitas Sumatera Utara. 1(1), 1-16.

Sugiyono. (2015). Metode Penelitian Kombinasi (Mix Methods). Bandung; Alfabeta.

Yulianti, N., \& Silvy, M. (2013). Sikap Pengelola Keuangan Dan Perilaku Perencanaan Investasi Keluarga Di Surabaya. Journal of Business and Banking, 57-68. 